\title{
Performance of tropical vertical subsurface flow constructed wetlands for leachate treatment at different hydraulic loading rates
}

\author{
T.A.O.K. Meetiyagoda ${ }^{1}$, N.J.G.J. Bandara ${ }^{2}$, K.B.S.N. Jinadasa ${ }^{3}$, C.S. Kalpage ${ }^{4}$ and C.D.K. \\ Pathirana ${ }^{2}$ \\ ${ }^{1}$ Postgraduate in Environmental and Water Engineering, Department of Civil Engineering, \\ University of Peradeniya \\ ${ }^{2}$ Department of Forestry and environmental science, University of Sri Jayewardenepura \\ ${ }^{3}$ Department of Civil Engineering, University of Peradeniya \\ ${ }^{4}$ Department of Chemical \& Process Engineering, University of Peradeniya
}

Date Received: 29-10-2017 Date Accepted: 20-12-2017

\begin{abstract}
This study is focused on the investigation of three different types of plant species namely; Narrow leaf Cattail (Typha angustifolia), Green Bulrush (Scirpus atrovirens) and Umbrella Palm (Cyperus alternifolius) for treatment of leachate. Twelve laboratory scale subsurface flow constructed wetland models were operated in batch mode. Four models, each containing similar plant species were fed with synthetic leachate having four different concentrations $(25 \%, 50 \%, 75 \%$ and $100 \%)$ and 7 days HRT was given. The duration of a batch run was 12 weeks. Removal efficiencies of $\mathrm{BOD}_{5}, \mathrm{COD}, \mathrm{PO}_{4}{ }^{3-}, \mathrm{TC}$, and TN were measured. Evapotranspiration (ET) loss of each test run was also assessed. According to the results, the constructed wetland planted with Umbrella palm and fed with $25 \%$ leachate showed the best pollutant removal efficiencies of $99.26 \%$ for $\mathrm{BOD}_{5}, 99.61 \%$ for COD, $98.78 \%$ for TN and $97.34 \%$ for TC. Highest ET potential of $93.57 \%$ was also observed from the constructed wetland with umbrella palm fed with $25 \%$ leachate. Two way ANOVA analysis was carried out for each plant species and leachate concentration and the Umbrella Palm species was identified as the best for leachate treatment.
\end{abstract}

Key words: Constructed wetlands, landfill leachate, plant species, pollutant removal

\section{Introduction}

Solid waste disposed in landfills are stabilized by combination of physical, chemical and microbial processes. As a result of landfill degradation, a liquid known as leachate is formed (Tyrrel et al., 2002). Landfill leachate is a highly complex wastewater. Due to anaerobic conditions and long retention times prevailing in landfills, the landfill leachate usually contains high concentrations of nutrients, organic compounds and heavy metals which, if not properly collected and treated, can cause serious pollution by contaminating surface and groundwater sources (Dorota and Ewa, 2008; Christansen et al., 1994). Although several physical, chemical and biological treatment processes can be employed to minimize adverse environmental impacts of landfill leachate, they can be expensive in the construction, operation and may also require high-skilled laborers for operation (Sawaittayothin and Polprasert, 2007).

*Correspondence: kasun.pgwe17@eng.pdn.ac.lk

Tel:

ISSN 2235-9370 Print / ISSN 2235-9362 Online (C University of Sri Jayewardenepura 
Constructed wetlands (CWs) are engineered systems which simulate the same processes that occur in natural wetlands, within a more controlled environment (Kadlec and Knight, 1996). CWs have reasonably a small ecological footprint, which has been designed and implemented in accordance with the natural processes involving wetland vegetation, soils, and the associated microbial assemblages to assist in treating wastewaters. These systems have been effective in treating various types of waste waters, due to its support for diverse population of microbial communities and it offers quiescent conditions for sedimentation, adsorption, filtration, and ion exchange (Cothren et al., 2002; Verhoeven et al., 2006).

Since CW systems could potentially tolerate variable volumes of water and varying contaminant levels, it is highly applicable for treating landfill leachate (Akinbile et al., 2012). Several studies have been conducted on the factors that can affect contaminant removal in CWs treating landfill leachate (Yalcuk et al., (2009). Lavrova et al., (2011) studied the effect of the flow direction on the treatment efficiency in the CWs. Kietlińska and Renman (2005) reported that recirculation of treated effluent positively effects the substrate media. The variation of the performance with the type of pre-treatment was reported by Wojciechowska et al., (2010). Although majority of previous studies had used domestic or municipal wastewater to investigate the role of the plant species in CWs (Allen et al., 2002), studies done on industrial wastewaters for example paper-mills (Abira et al., 2003), tannery (Calheiros, et al., 2007), and fish-farm (Naylor et al., 2003) and ground water (Lin et al., 2002) are also available. The effect of loading rates was the most common factor evaluated along with plant species (Brisson and Chazarenc, 2008). Two or more loading rates were either evaluated simultaneously with plant species in a factorial experimental design (with or without replicates) or by modifying loading rates over time in the same units and comparing the different time series.

It is commonly accepted that macrophytes play an essential role in CWs. Brix (1997) and Stottmeister et al. (2003) reported that macrophytes provide a large surface area for an attached microbial growth and supply reduced carbon and oxygen in the rhizosphere. The reduced flow velocity by macrophytes stabilized the surface of the bed and insulated the surface against frost in the winter. Previous studies indicated that the type of the plant is often considered minor in subsurface flow CWs for pollutant removal (Mander et al., 2003), while some other studies revealed that the growth characteristics of different plant species may affect the potential for uptake and transformation of nutrient and heavy metals (Tanner, et al., 1996; Maltais-Landry et al., 2009).Benefits of macrophytes have been repeatedly demonstrated, but, it remains unclear whether significant differences exist in the removal efficiencies among plant species of comparable life forms and sizes (Brisson and Chazarenc, 2008). Even though several CW studies with plant species are reported in the literature, there has been a dearth of information on the assessment of plant species on the removal efficiency of contaminants from landfill leachate. Therefore, the primary objective of this study is to i) evaluate the effect of plant species towards the CW performance when treating landfill leachate; and ii) to find the most appropriate leachate concentration to be introduced to a constructed wetland system.

\section{Materials and Method}

\subsection{Plant Species}

Three plant species namely narrow leaf Cattail (Typha angustifolia), green Bulrush (Scirpus atrovirens) and Umbrella Palm (Cyperus alternifolius), were selected for this study. 


\subsection{Experimental design}

Twelve (12) identical lab scale subsurface flow constructed wetland (SSF CW) models were constructed using plastic vessels each with dimensions of $25 \mathrm{~cm} \times 20 \mathrm{~cm} \times 34 \mathrm{~cm}$ (length $\times$ width $\times$ depth). A sampling point (faucet) was fixed at $3 \mathrm{~cm}$ from the bottom of each $\mathrm{CW}$ model for the collection of treated effluents. The faucet inlet was covered with a plastic net to prevent debris from clogging the sampling point. Gravel, sand and silt were used as the substrate media in each CW. A $15 \mathrm{~cm}$ gravel layer, $10 \mathrm{~cm}$ sand layer and a $5 \mathrm{~cm}$ loam soil layer were placed from bottom to top to facilitate favorable conditions for plant growth. A plastic net was placed between soil and gravel layers to minimize disturbances to the silt layer. One plant species was planted in $4 \mathrm{CWs}$ so that 12 models were planted with 3 species of plants. Plant density in each model was maintained at 3 shoots per $\mathrm{CW}$.

\subsection{Synthetic leachate}

Stock solution of synthetic leachate was prepared according to the formula presented by Jamie et al., (2004). The concentration of synthetic leachate is given in Table 1. Four different feed solutions $(25 \%, 50 \%, 75 \%$ and $100 \%$ of stock concentrations) were prepared by diluting the stock solution with normal tap water.

Table 1: Synthetic leachate composition

\begin{tabular}{|c|c|}
\hline Common chemical & Unit: g per liter \\
\hline Sugar & $1000 \mathrm{~g}$ \\
\hline $\mathrm{CH}_{3} \mathrm{COONa}$ & $100 \mathrm{~g}$ \\
\hline $\mathrm{K}_{2} \mathrm{HPO}_{4}$ & $2.22 \mathrm{~g}$ \\
\hline $\mathrm{NaHCO}_{3}$ & $35.72 \mathrm{~g}$ \\
\hline $\mathrm{K}_{2} \mathrm{CO}_{3}$ & $35.37 \mathrm{~g}$ \\
\hline $\mathrm{NaCl}$ & $9.96 \mathrm{~g}$ \\
\hline $\mathrm{CaCl}_{2}$ & $15.96 \mathrm{~g}$ \\
\hline $\mathrm{MgCl}_{2} \cdot 6 \mathrm{H}_{2} \mathrm{O}$ & $15.89 \mathrm{~g}$ \\
\hline $\mathrm{MgSO}_{4} \cdot 7 \mathrm{H}_{2} \mathrm{O}$ & $8.04 \mathrm{~g}$ \\
\hline $\mathrm{CO}\left(\mathrm{NH}_{2}\right)_{2}$ & $1000, \mathrm{~g}$ \\
\hline Trace heavy metal & Unit: mg per liter \\
\hline $\mathrm{FeSO}_{4}$ & 200 \\
\hline $\mathrm{H}_{3} \mathrm{BO}_{4}$ & 5 \\
\hline $\mathrm{ZnSO}_{4} .7 \mathrm{H}_{2} \mathrm{O}$ & 5 \\
\hline $\mathrm{CuSO}_{4} .5 \mathrm{H}_{2} \mathrm{O}$ & 4 \\
\hline $\mathrm{MnSO}_{4} .7 \mathrm{H}_{2} \mathrm{O}$ & 50 \\
\hline$\left(\mathrm{NH}_{4}\right)_{6} \mathrm{Mo}_{7} \mathrm{O}_{24} \cdot 4 \mathrm{H}_{2} \mathrm{O}$ & 5 \\
\hline $\mathrm{Al}\left(\mathrm{SO}_{4}\right)_{3} .16 \mathrm{H}_{2} \mathrm{O}$ & 3 \\
\hline $\mathrm{CoSO}_{4} .7 \mathrm{H}_{2} \mathrm{O}$ & 15 \\
\hline $\mathrm{NiSO}_{4} \cdot 6 \mathrm{H}_{2} \mathrm{O}$ & 50 \\
\hline $96 \%$ conc. $\mathrm{H}_{2} \mathrm{SO}_{4}$ (AnalR) & $1 \mathrm{ml}$ \\
\hline
\end{tabular}




\subsection{Leachate loading}

Initially all $12 \mathrm{CW}$ models were fed with tap water and allowed for plant shoots to stabilize (to develop couple of leaves). Once stabilised, the first $\mathrm{CW}$ model was fed with $5 \mathrm{~L}$ of $25 \%$ leachate using a watering can, manually. The second $\mathrm{CW}$ model with the same plant species was fed with $50 \%$ leachate solution, the third one with $75 \%$ and the last one with $100 \%$ solutions. This procedure was repeated for all 3 types of plants species. CW models were operated in batch mode with a hydraulic retention time (HRT) of 7 days. After keeping intact for 7 days, leachate was drained through the sampling faucet. The leachate volume remaining after 7 days of batch operation was also measured. Water quality was tested for 5-day biochemical oxygen demand $\left(\mathrm{BOD}_{5}\right)$, chemical oxygen demand (COD), total nitrogen (TN), phosphate concentration $\left(\mathrm{PO}_{4}{ }^{3-}\right)$ and total carbon concentration (TC). The above procedure was repeated for all 12 models for 12 consecutive batches.

\subsection{Evapotranspiration (ET) Loss}

In CWs, reduction of wastewater volume occurs with time due to both evaporation and transpiration, which is known as the Evapotranspiration (ET) loss. This may have an effect on the treatment efficiency of CWs. The ET loss was estimated as per the equation 1.

ET loss $=\frac{(5-\text { leachate volume in litres remaining after } 7 \text { days of retention period })}{5} \times 100$

\subsection{Statistical analysis}

Pollutant removal efficiencies of 5 selected parameters $\left(\mathrm{COD}, \mathrm{BOD}_{5}, \mathrm{TN}, \mathrm{TC}, \mathrm{PO}_{4}{ }^{3-}\right)$ were estimated according to the equation 2 .

$$
\text { Removal efficiency }=\frac{\text { Initial concentration }- \text { Final concentration }}{\text { initial concentration }} \times 100
$$

Removal efficiencies obtained from $12 \mathrm{CWs}$ for 12 repeated tests were subjected to two way ANOVA analysis. The analysis was conducted using Minitab (16.2.4.0) software. The analysis was conducted to determine significant differences among different systems and comparison of means was done in order to find the most appropriate plant species and best leachate concentration for the optimal removal of contaminants.

\section{Results and Discussion}

In this study three plant species (Cattail, Bulrush and Umbrella palm) were grown in 12 identical SSF CW sand tested for 4 different leachate concentrations $(25 \%, 50 \%, 75 \%$ and $100 \%$ of stock leachate concentration). Tests were conducted in batch mode with a 7 day HRT. Pollutant removal efficiencies of $\mathrm{BOD}_{5}, \mathrm{COD}, \mathrm{PO}_{4}{ }^{3-}, \mathrm{TC}$, and $\mathrm{TN}$ were estimated. Percentage reduction of leachate volume during the 7 day retention period was also assessed. Since the pollutant levels in natural leachate could vary with the climatic condition, solid waste composition and many other variables; synthetic leachate prepared according to the formula presented by Jamie et al. (2004) was used for this study. Composition of the stock leachate solution is given in Table 2. 
Table 2: Concentration of synthetic leachate stock solution.

\begin{tabular}{lll}
\hline Pollutant Parameter & Value & Detection Method \\
\hline BOD & 442.7 & Winkler method \\
COD & 2600 & Reactor digestion method \\
PO $_{4}{ }^{-}$ & 4.31 & PhosVer 3 (Ascorbic Acid) method \\
TC & 1217.7 & TOC analyzer \\
TN & 1039.4 & TOC analyzer \\
\hline
\end{tabular}

After leachate was introduced to constructed wetland systems, moss layers had appeared in the $25 \%$ and $50 \%$ leachate fed systems within a couple of days. However, after few weeks of operations similar moss layers had appeared in the $75 \%$ and $100 \%$ leachate systems. This observation indicated that the feed concentrations in 25\% and 50\% CWs can readily be used by primitive life forms, but higher feed concentration (75\% and above) need a comparatively long period for such life forms to proliferate in harsher environmental conditions. Plants in CWs except cattail with $75 \%$ and $100 \%$ leachate showed a good tolerance against leachate. After about two months from initiation, cattail shoots in the $100 \%$ and $75 \%$ systems appeared to be dried and destroyed, but new shoots appeared in the $3^{\text {rd }}$ month. Umbrella palm shoots showed a better tolerance for leachate as the plant growth was not disturbed by the application of leachate.

\subsection{Evapotranspiration}

A significant ET loss has occurred in all CWs, especially in systems fed with $25 \%$ and $50 \%$ leachate (Figure 1). This may be due to the evaporation which has occurred due to high air temperature and low humidity on top of increased transpiration due to the plant growth. In tropical countries a considerable amount of water evaporates from water bodies especially under warm and windy conditions. Certain percentage $(\sim 95 \%)$ of water absorbed by the plant roots has also escaped from the small pores in leaves (transpiration). The amount of transpiration varies from plant to plant. According to the Białowiec and Wojnowska-Baryla (2007) and Headley et al. (2012) water losses through transpiration is high in Macrophytes as they have inherently low efficiencies of water use. Of the three plant species, the highest ET rate against four different leachate loading was observed in umbrella palm plants (71.95\%).

Evapotranspiration losses have significantly changed with the leachate concentration. The mean ET losses for leachate concentrations in $25 \%, 50 \%, 75 \%$ and $100 \%$ CWs were $78.04 \%, 69.78 \%, 53.27 \%$ and $41.26 \%$, respectively. Results indicated that Umbrella palm containing CWs with25\% leachate concentrations exhibited the highest ET potential. 


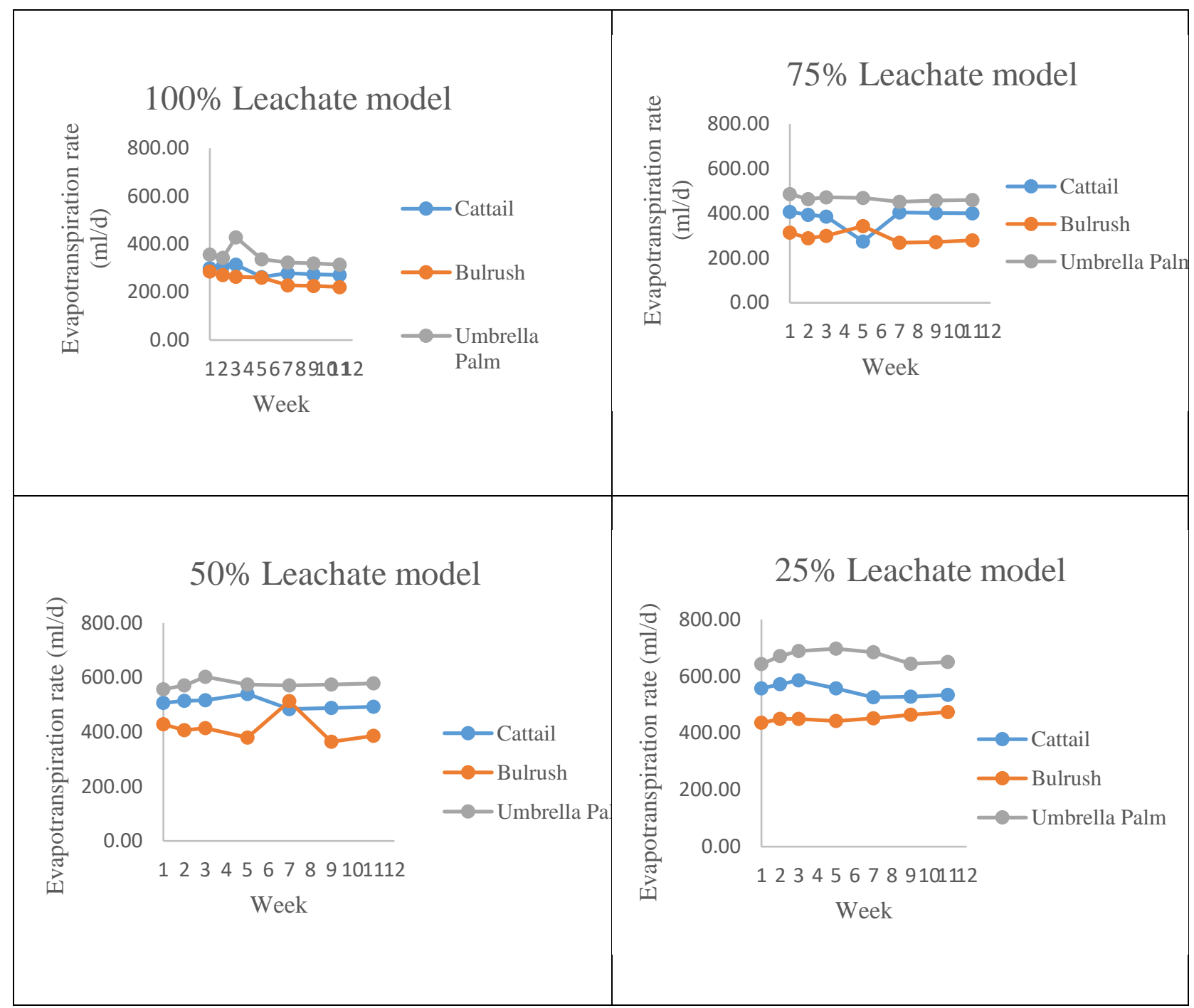

Figure 1: Different evapotranspiration models

\subsection{Treatment performance}

All CW units performed well in the treatment of synthetic leachate, maintaining a high removal efficiency at all tested conditions. This section contains the results of the batch tests for the removal of $\mathrm{BOD}_{5}, \mathrm{COD}, \mathrm{TN}, \mathrm{TC}$ and $\mathrm{PO}_{4}{ }^{3-}$.

$\mathrm{BOD}_{5}$

Results of statistical analysis indicated that both the plant species and the leachate concentrations have significant impacts $(\mathrm{P}<0.05)$ on $\mathrm{BOD}_{5}$ removal efficiencies. The highest mean $\mathrm{BOD}_{5}$ removal efficiency was reported by Umbrella palm plants for $25 \%$ leachate concentration (Figure 2).

$C O D$

All three plant species showed good performance in COD removal with removal efficiencies of above $70 \%$ in all testes (Table 3.2). A slight decrease of removal efficiency with time was shown by 
Cattail and Green bulrush species against $100 \%$ leachate. Even though a considerable drop had occurred in the $9^{\text {th }}$ week, umbrella palm exhibited the highest average removal efficiency $(89.62 \pm 3.62 \%)$.

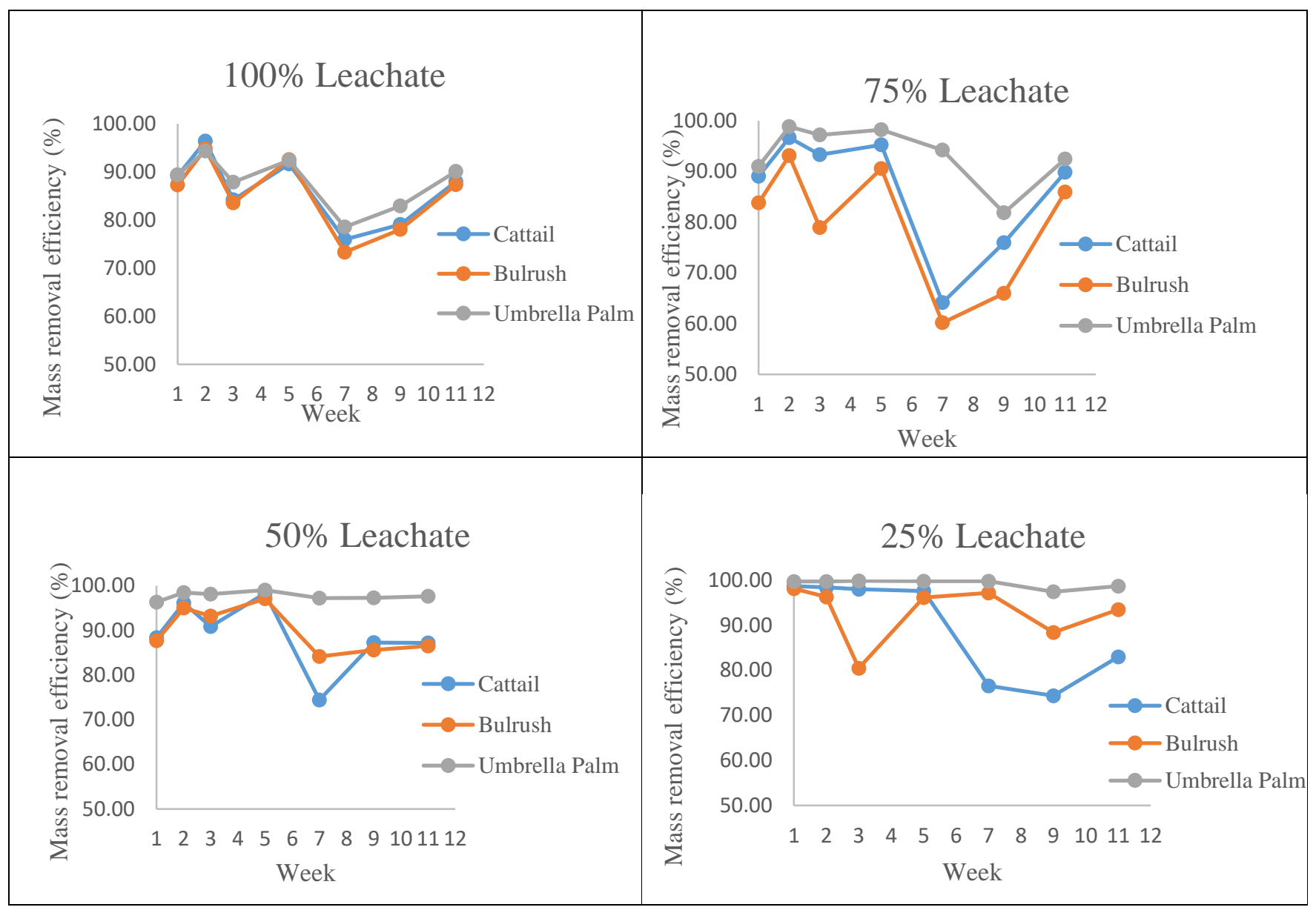

Figure 2: BOD removal efficiencies in the presence of different plant species under different leachate loading.

Table 3: COD removal efficiencies in the presence of different leachate loading rate.

\begin{tabular}{lllll}
\hline & $100 \%$ loading & $75 \%$ loading & $50 \%$ loading & $25 \%$ loading \\
\hline Typha angustifolia & $83.06 \pm 6.16 \%$ & $88.69 \pm 6.96 \%$ & $96.16 \pm 1.99 \%$ & $99.14 \pm 0.95 \%$ \\
Scirpus atrovirens & $79.66 \pm 5.41 \%$ & $85.62 \pm 5.10 \%$ & $87.75 \pm 3.81 \%$ & $98.24 \pm 2.08 \%$ \\
Cyperus alterufolius & $89.62 \pm 3.62 \%$ & $96.52 \pm 2.24 \%$ & $98.73 \pm 1.20 \%$ & $99.61 \pm 0.39 \%$ \\
\hline
\end{tabular}

Comparatively higher average COD removal efficiencies were observed in CWs with 50\% loading than CW systems with $75 \%$ and $100 \%$ leachate. In this concentration range also, the highest average removal efficiency was reported by Umbrella Palm. The highest COD removal efficiencies and lowest 
variance induced by plant species was observed in CWs with $25 \%$ leachate loading. All three plant species performed well at the lowest leachate concentration.

Total Nitrogen (TN)

In the presence of concentrated leachate (100\%), the CWs planted with Cattail had shown a significantly high $(\mathrm{p}<0.05) \mathrm{TN}$ removal. Even though the value had dropped after the first feeding, the removal efficiency still remained at a higher level $(73.54 \pm 2.45 \%)$. Removal efficiency of the system with Green bulrush remained stable at around $70 \%$ after the first 5 weeks. The CW with Umbrella palm exhibited the highest average removal efficiency of $76.40 \pm 3.99 \%$. Performances of plant species at different leachate concentrations are given in (Figure 3).

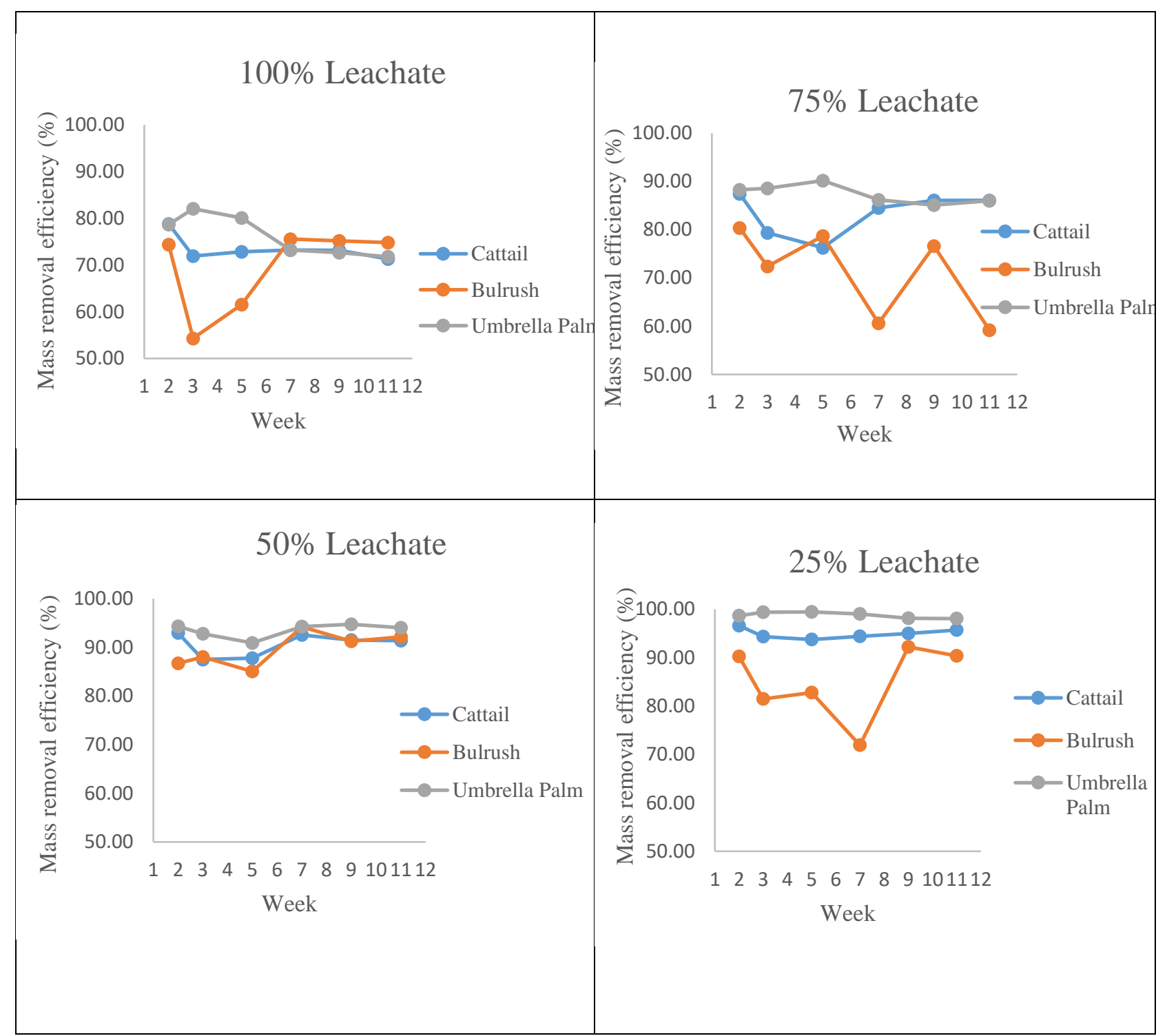

Figure 3: TN removal efficiencies in the presence of different plant species under different leachate loading. 
For both Cattail and Green bulrush, the TN removal efficiencies exhibited almost constant values, regardless of the leachate loading. The $\mathrm{CW}$ with Umbrella palm showed the highest average TN removal efficiency among the 12 tested twelve models, regardless of leachate loading. The highest removal efficiency was observed in CWs at $25 \%$ leachate loading (97.34\%).

The plant species and the loading strength of leachate showed a significant $(\mathrm{P}<0.05)$ impact on $\mathrm{TN}$ removal. The interaction between TN removal, plant species and loading strength was also significant (P $<0.05)$.

\section{Total Carbon (TC)}

In CWs, the organic carbon is converted to $\mathrm{CO}_{2}$ or $\mathrm{CH}_{4}$ by microbial degradation and is absorbed by plants for cell synthesis. Carbon removal is major function of CWs. Therefore TC removal efficiency by different plant species was also studied. Slight decrease of TC removal efficiency with time was observed in all treatment systems which is attributed to initial adsorption by the materials in CWs.

Models planted with Green bulrush showed the poorest TC removal efficiencies ranging from $67.97 \%$ to $82.83 \%$. The highest removal efficiencies $(88.72-97.34 \%)$ were exhibited by CWs planted with Umbrella palm. The CW planted with Umbrella palm and fed with $25 \%$ leachate showed the highest average TC removal efficiency at $97.34 \pm 1.40 \%$.

The P-value of less than 0.05 indicates that significant differences exist in TC removal efficiencies in the CWs with different plant species and different leachate loadings (Figure 4).

\section{Phosphate $\left(\mathrm{PO}_{4}{ }^{3-}\right)$}

In $\mathrm{CWs}, \mathrm{PO}_{4}{ }^{3-}$ may be removed by plant uptake; therefore the type of plant species may have a great influence on $\mathrm{PO}_{4}{ }^{3-}$ removal.All three systems showed a high $\mathrm{PO}_{4}{ }^{3-}$ removal capacity of above $88 \%$. The highest $\mathrm{PO}_{4}{ }^{3-}$ removal efficiencies (96.16-98.45\%) were observed in Umbrella palm planted models, regardless of the leachate concentration, while Green bulrush exhibited the lowest performance $(88.70$ $94.41 \%)$. The highest average removal efficiency was registered by Umbrella palm at $25 \%$ leachate concentration. As the p-values of plant species, leachate concentrations and interactions are less than 0.05 , it can be concluded that significant differences in $\mathrm{PO}_{4}{ }^{3-}$ removal efficiencies are existing among those parameters (Figure 5).

\subsection{Effluent standard}

To find out the optimal concentration of leachate to be fed to CWs, the effluent COD and BOD5 values of each system were compared with the Central Environmental Authority (CEA) discharge standards (Gazette No. 1534/18, 2008). The CEA effluent discharge standards for COD and BOD5 are $250 \mathrm{mg} / \mathrm{L}$ and $30 \mathrm{mg} / \mathrm{L}$, respectively. It was observed that both standards were satisfactorily achieved in CWs planted with Umbrella palm and fed with $25 \%$ and $50 \%$ leachate concentrations. But CWs with other plant species were capable of achieving the COD and BOD5permissible discharge levels only in systems fed with $25 \%$ leachate concentration. 


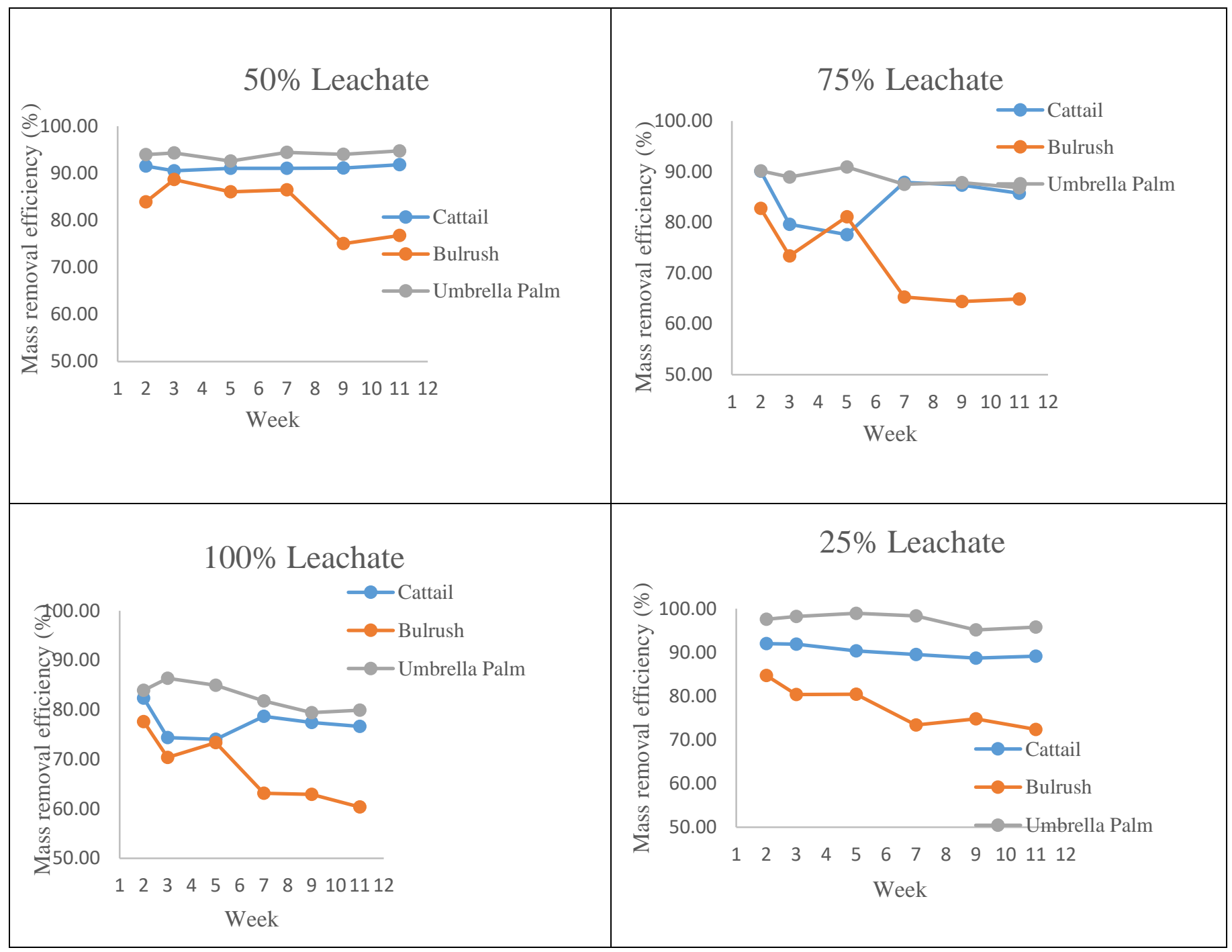

Figure 4: TC removal efficiencies in the presence of different plant species under different leachate loading. 


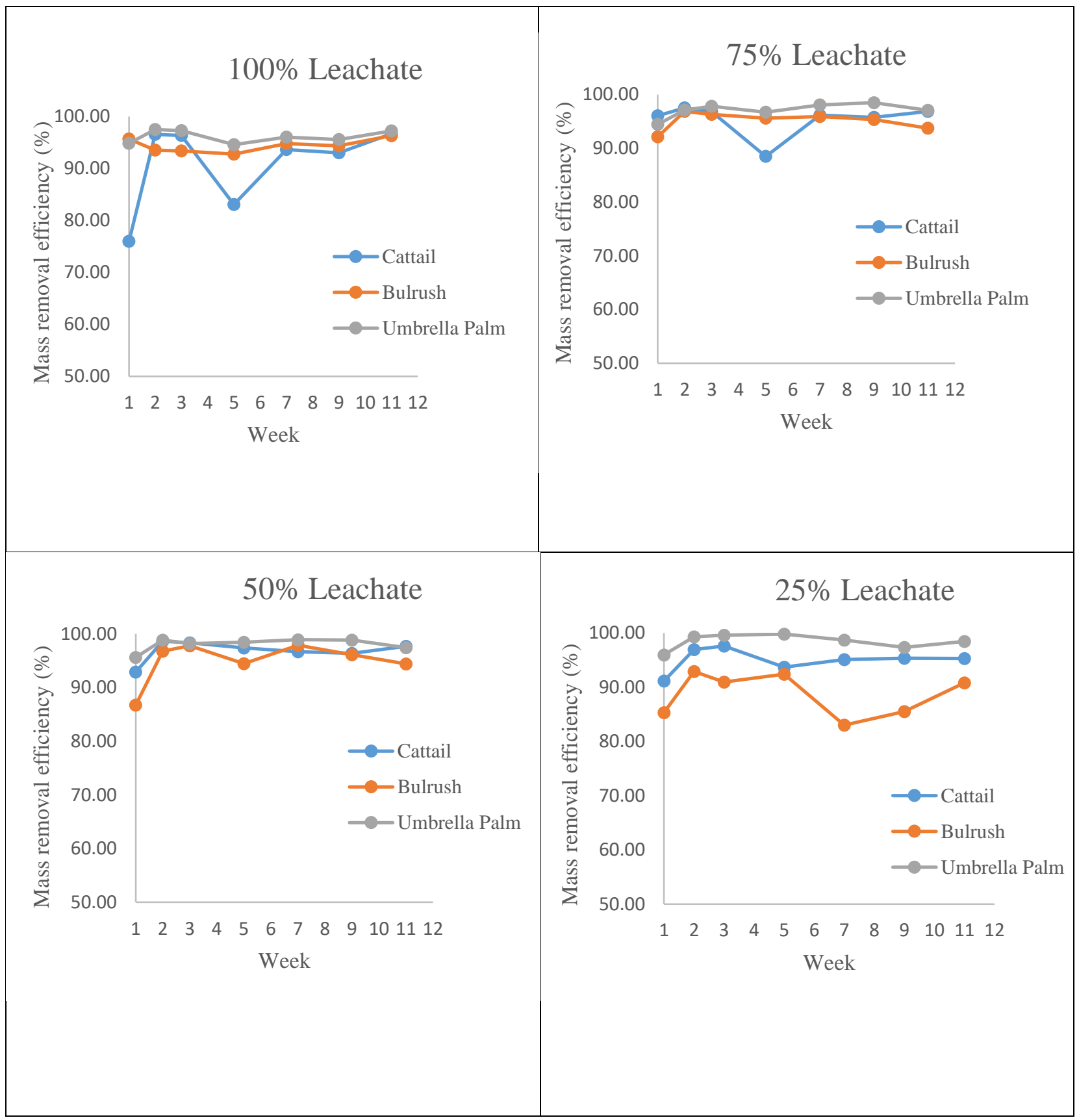

Figure 5: $\mathrm{PO}_{4}{ }^{3-}$ removal efficiencies in the presence of different plant species under different leachate loading.

\section{Conclusions}

Twelve (12) identical SSF CW models were planted with 3 plant species and fed with 4 different leachate concentrations. Stock synthetic leachate solution was prepared and diluted to 4 concentrations $(25 \%, 50 \%, 75 \%$ and $100 \%)$ as the feed solutions. Pollutant (COD, BOD 5, TN, TC and $\mathrm{PO}_{4}{ }^{3-}$ ) removal efficiencies obtained from several batch tests were subjected to two-way ANOVA analysis and statistical differences among systems were assessed. The mean comparisons were performed using basic statistical 
analysis to find out the best plant species and best feed concentration. Effluent concentrations were compared against permissible discharge standards.

Fluctuations in removal efficiencies were observed in all tested models, which is normal in any living biological system. All 3 plant species performed satisfactorily well for leachate concentrations of $25 \%$ according to the CEA permissible discharge standards. The highest average pollutant removal efficiencies were observed in CWs planted with Umbrella palm (Cyperus alterufolius) for all leachate concentrations. The result of Two way ANOVA tests indicated that a significant difference exists among the three plant species and four feed concentrations in removing all tested pollutant parameters. Therefore, mean comparisons were performed to find out the plant species and concentrations corresponding to the best treatment.

Umbrella palm exhibited the best removal efficiencies for all parameters irrespective of leachate concentration. The results gained from two-way ANOVA comparing the performance of the plant species independent of leachate concentration also proved that the same plant species is significantly efficient, in treatment of leachate.

Mean Comparisons were performed using Minitab software to find the concentration corresponding to the best treatment efficiency irrespective of the plant species. The best removal efficiencies in removing BOD, COD and TN were given by $25 \%$ leachate, while $50 \%$ leachate has been given the best removal efficiency of $\mathrm{TC}$ and $\mathrm{PO}_{4}{ }^{3-}$. Evapotranspiration studies recorded a significantly higher loss for all plant species at all leachate concentrations. This was attributed to the tropical climate conditions of the study location. The significant differences among the ET potential for different plant species were observed. Evapotranspiration rates were also significantly changed with the leachate concentration. The highest ET loss rate was reported in CWs containing umbrella palm plants and fed with $25 \%$ leachate.

\section{References}

Abira, M.A., Ngirigacha, H.W. and Van Bruggen, J.J.A., 2003. Preliminary investigation of the potential of four tropical emergent macrophytes for treatment of pre-treated pulp and papermill wastewater in Kenya. Water science and technology, 48(5), pp.223-231.

Akinbile, C.O., Yusoff, M.S. and Zuki, A.A., 2012. Landfill leachate treatment using sub-surface flow constructed wetland by Cyperushaspan. Waste management, 32(7), pp.1387-1393.

Allen, W.C., Hook, P.B., Biederman, J.A. and Stein, O.R., 2002. Temperature and wetland plant species effects on wastewater treatment and root zone oxidation. Journal of Environmental Quality, 31(3), pp.1010-1016.

Brix, H., 1997. Do macrophytes play a role in constructed treatment wetlands?. Water science and technology, 35(5), pp.11-17.

Cothren, G.M., Chen, S. and Pardue, J.H., 2002. Investigation of subsurface flow constructed wetland designs. Public Works Management \& Policy, 7(1), pp.32-45.

Gazzatte No. 1534/18. 2008. Schedule I- Tolerance Limits For The Discharge of Industrial Waste into Inland Surface Waters, The Gazette of the Democratic Socialist Republic of Sri Lanka.

Justin, M.Z. and Zupančič, M., 2009. Combined purification and reuse of landfill leachate by constructed wetland and irrigation of grass and willows. Desalination, 246(1-3), pp.157-168.

Kadlec, R.H. and Knight, R.L., 1996. Treatment wetlands. CRC. Baca Raton, FL.

Kietlińska, A. and Renman, G., 2005. An evaluation of reactive filter media for treating landfill leachate. Chemosphere, 61(7), pp.933-940. 
Kulikowska, D. and Klimiuk, E., 2008. The effect of landfill age on municipal leachate composition. Bioresource Technology, 99(13), pp.5981-5985.

Lavrova, S. and Koumanova, B., 2010. Influence of recirculation in a lab-scale vertical flow constructed wetland on the treatment efficiency of landfill leachate. Bioresource technology, 101(6), pp.17561761.

Lin, X., Lan, C. and Shu, W., 2003, October. Treatment of landfill leachate by subsurface-flow constructed wetland: a microcosm test. In Proceedings of the third international conference on vetiver and exhibition: vetiver and water. Guangzhou, China (pp. 216-223).

Lin, Y.F., Jing, S.R., Wang, T.W. and Lee, D.Y., 2002. Effects of macrophytes and external carbon sources on nitrate removal from groundwater in constructed wetlands. Environmental pollution, 119(3), pp.413-420.

Mander, Ü.,Teiter, S., Kuusemets, V., Lohmus, K., Öövel, M., Nurk, K. and Augustin, J., 2003. Nitrogen and phosphorus budgets in a subsurface flow wastewater treatment wetland. WIT Transactions on Ecology and the Environment, 61.

Naylor, S., Brisson, J., Labelle, M.A., Drizo, A. and Comeau, Y., 2003. Treatment of freshwater fish farm effluent using constructed wetlands: the role of plants and substrate. Water Science and Technology, 48(5), pp.215-222.

Pendleton, C.H., Morris, J.W.F., Goldemund, H., Rozema, L.R., Mallamo, M. and Agricola, S.L., 2005. Leachate treatment using vertical subsurface flow wetland systems-findings from two pilot studies. In R. Cossu and R. Stegmann eds., 10th International Waste Management and Landfill Symposium, Environmental Sanitary Engineering Centre (pp. 727-728).

Sawaittayothin, V. and Polprasert, C., 2007. Nitrogen mass balance and microbial analysis of constructed wetlands treating municipal landfill leachate. Bioresource Technology, 98(3), pp.565-570.

Sawaittayothin, V. and Polprasert, C., 2007. Nitrogen mass balance and microbial analysis of constructed wetlands treating municipal landfill leachate. Bioresource Technology, 98(3), pp.565-570.

Stottmeister, U., Wießner, A., Kuschk, P., Kappelmeyer, U., Kästner, M., Bederski, O., Müller, R.A. and Moormann, H., 2003. Effects of plants and microorganisms in constructed wetlands for wastewater treatment. Biotechnology advances, 22(1), pp.93-117.

Tanner, C.C., 1996. Plants for constructed wetland treatment systems - a comparison of the growth and nutrient uptake of eight emergent species. Ecological engineering, 7(1), pp.59-83.

Tyrrel, S.F., Leeds-Harrison, P.B. and Harrison, K.S., 2002. Removal of ammoniacal nitrogen from landfill leachate by irrigation onto vegetated treatment planes. Water Research, 36(1), pp.291-299.

Verhoeven, J.T., Arheimer, B., Yin, C. and Hefting, M.M., 2006. Regional and global concerns over wetlands and water quality. Trends in ecology \& evolution, 21(2), pp.96-103.

Wojciechowska, E., Gajewska, M. and Obarska-Pempkowiak, H., 2010. Treatment of landfill leachate by constructed wetlands: three case studies. Polish Journal of Environmental Studies, 19(3), pp.643650 .

Yalcuk, A. and Ugurlu, A., 2009. Comparison of horizontal and vertical constructed wetland systems for landfill leachate treatment. Bioresource Technology, 100(9), pp.2521-2526. 